\title{
Communication/Comunicação
}

\section{Epidemiological profile of acute bacterial meningitis in the State of Rio Grande do Norte, Brazil}

\author{
Perfil epidemiológico da meningite bacteriana aguda no Estado do Rio Grande do Norte, \\ Brasil
}

\author{
Wallace Andrino da Silva ${ }^{1}$, Aline Macêdo Pinheiro ${ }^{1}$, Leonam Gomes Coutinho ${ }^{1}$, Luis Alberto Carneiro Marinho ${ }^{2}$ \\ and Lucymara Fassarella Agnez Lima ${ }^{1}$
}

\begin{abstract}
Introduction: Acute bacterial meningitis $(\mathrm{ABM})$ remains a public health problem in Brazil. To evaluate the epidemiology of ABM cases at Giselda Trigueiro Hospital, Rio Grande do Norte, a descriptive retrospective survey was conducted covering 2005 to 2008. Methods: Clinical and laboratory data were collected from the epidemiology department of the hospital and analyzed. Results: Out of 168 ABM cases, $24.4 \%, 10.7 \%$, and $2.4 \%$ were, respectively, caused by Streptococcus pneumoniae, Neisseria meningitidis and Haemophilus influenza $b$, and $5.4 \%$ by other bacteria. The mean age was $22.48 \pm 18.7$ years old. Conclusions: Streptococcus pneumoniae was the main causative pathogen in the young urban population.
\end{abstract}

Key-words: Bacterial meningitis. Epidemiology. Brazil.

\section{RESUMO}

Introdução: Meningite bacteriana aguda (MBA) permanece um problema de saúde pública no Brasil. Para avaliar a epidemiologia da MBA atendida no Hospital Giselda Trigueiro, Rio Grande do Norte, um estudo retrospectivodescritivo foi realizado de 2005 a 2008. Métodos: Dados clínicos e laboratoriais foram coletados do departamento de epidemiologia hospitalar e analisados. Resultados: Dos 168 casos de MBA, 24,4\%, 10,7\% e 2,4\% foram, respectivamente, causados por Streptococcus pneumoniae, Neisseria meningitidis e Haemophilus influenzae b e 5,4\% por outras bactérias. A média da idade foi 22,48 \pm 18,7 anos. Conclusões: Streptococcus pneumoniae foi o principal patógeno causador na população urbana jovem.

Palavras-chaves: Meningite bacteriana. Epidemiologia. Brasil.

Acute bacterial meningitis $(A B M)$ is a public health problem worldwide and, in Brazil, in the 1990s, an average of 28,000 cases of meningitis were reported annually ${ }^{1}$. In an etiological survey in northeastern Brazil in the 1980s, Bryan et $\mathrm{al}^{2}$ reported that $N$. meningitides (meningococcus) was the most prevalent $\mathrm{ABM}$ pathogen, followed by Haemophilus influenzae type $\mathrm{b}(\mathrm{Hib})$ and Streptococcus pneumoniae (pneumococcus) ${ }^{2}$. However, after the introduction of the anti-Hib conjugated vaccine to the public vaccination program in 1999, there was a significant decrease in the incidence of cases of ABM due to H. influenzae in Brazil ${ }^{3}$.

1.Laboratory of Molecular Biology and Genomics, Department of Cell Biology and Genetics, Center for Biosciences, Federal University of Rio Grande do Norte, Natal, RN, Brazil. 2. Reference Hospital for Infectious Diseases Giselda Trigueiro, Natal, RN, Brazil.

Address to: Dr. Wallace Andrino da Silva. Laboratório Biol Mol e Gen/DBG/Centro de Biociências/UFRN. Campus Lagoa Nova s/n. 59072-970 Natal, RN, Brasil. Phone: 5584 3211-9209; Fax: 5584 3215-3425

e-mail: wallaceandrino@yahoo.com.br

Received in 16/02/2010

Accepted in 20/05/2010
Because of the high mortality rate and long-term sequels, fast and accurate diagnosis and appropriate treatment of $A B M$ are fundamental for a good outcome ${ }^{4}$. The initial antibiotic regimen is usually empirical, and therefore, knowledge of the epidemiological profile of $A B M$ in the community could lead to the best therapeutic choice ${ }^{5}$.

In the present study, we describe the epidemiological profile of ABM at Giselda Trigueiro Hospital (GTH), a reference center for infectious diseases in the State of Rio Grande do Norte, Brazil, between 2005 and 2008. We are not aware of any previous study on the epidemiology of $\mathrm{ABM}$ in this Brazilian state.

This study consisted of a descriptive retrospective survey of the cases of ABM that were attended at GTH between 2005 and 2008. During the period of this study, the hospital could not afford a pediatric ward, and children were sent to pediatric hospitals after diagnosis and initial treatment.

Information on age, sex, home location (rural or urban area), laboratory results, criteria for diagnostic confirmation, previous use of antibiotics and outcome were collected from the official records of the Brazilian compulsory notification system (SINAN), which were available in the hospital's epidemiology department. The data were analyzed through SPSS (Statistical Package for the Social Sciences), version 13.0.

The diagnoses of cases with clinical signs and symptoms of ABM were confirmed in accordance with at least one of the following criteria: 1) cerebrospinal fluid (CSF) culture; 2) CSF Gram stain; 3) blood culture or blood Gram stain; 4) latex agglutination test on CSF; and 5) CSF presenting pleocytosis ( $>500$ cells $/ \mathrm{mm}^{3}$ ), predominantly polymorphonuclear neutrophils, protein level $>40 \mathrm{mg} / \mathrm{dl}$ and glucose level $<40 \mathrm{mg} / \mathrm{dl}$. Two cases did not fit the above criteria and their diagnosis were confirmed post-mortem by means of autopsy.

Blood and CSF were seeded in chocolate agar enriched with $5 \%$ sheep blood. The latex agglutination test was used to identify polysaccharide antigens from $N$. meningitides, $S$. pneumoniae and $\mathrm{Hib}$ in CSF. Gram's method consisted of a primary stain with crystal violet, followed by the addition of iodine, rapid decolorization with acetone, and staining with basic fuchsin.

The antibiotic susceptibility of the S. pneumoniae was identified by means of the disk diffusion method, in accordance with the definitions of the National Committee for Clinical Laboratory Standards (NCCLS, 1998).

This study was granted approval by the National Ethics Commission, under the number 0052.1.051.000-05. 
Between January 2005 and December 2008, 168 cases of ABM were admitted to the GTH, among which 107 (63.7\%) were male, $60(35.7 \%)$ were female, and one $(0.6 \%)$ was not identified by gender in the notification record. The mean age and standard deviation was $22.48 \pm 18.7$ years old (ranging from one month old to 78 years old). The mean ages according to the etiological agents were 29.8 years old for pneumococcus, 20.5 years old for meningococcus and 12.5 years old for Hib. Regarding the location of the patients' homes, $123(73.2 \%)$ were in urban areas, $28(16.7 \%)$ in rural areas and $17(10.1 \%)$ in intermediate areas.

Out of the 168 cases in our sample, 96 (57.1\%) were not identified according to etiological agent, while 41 (24.4\%) were caused by S. pneumoniae, 18 (10.7\%) by N. meningitidis, four (2.4\%) by $\mathrm{Hib}$ and nine $(5.4 \%)$ by other bacteria, namely Staphylococcus aureus (two cases), Salmonella (two cases), Streptococcus viridans (two cases), Klebsiella (two cases) and Proteus mirabilis (one case). The diagnostic criteria used according to the etiology are shown in Table 1. Blood or CSF cultures were positive for only 47 patients (28.0\%). Previous use of antibiotics at least 24 hours before the diagnosis and initial treatment of $A B M$ was reported for 11 (6.5\%) patients.

Sequels after meningitis were recorded before discharge in 16 patients (9.5\% of the cases), among which hearing loss was the most frequent. Of the three cases of hearing loss, one was related to chronic otitis media and another to trauma. The mortality rate among the sample was $11.3 \%$ (19 cases), and S. pneumoniae was responsible for the highest lethality rate (Table 2 ).

Seven cases of ABM due to S. pneumoniae were associated with skull-brain trauma, six cases were due to CSF fistula, and one case was due to chronic otitis media. The antibiotic sensitivity of S. pneumoniae was tested in 20 samples (Table 3).

Among the 18 cases of meningococcal ABM, N. meningitidis type $\mathrm{B}$ was identified in 11 cases and N. meningitidis type $\mathrm{C}$ in two cases. The mortality rate was $11.1 \%$ (Table 2), and N. meningitidis type B was the cause of all of the deaths.

TABLE 1 - Diagnostic methods according to the etiological agent of ABM.

\begin{tabular}{lcccccc}
\hline & \multicolumn{7}{c}{ Etiological agent } \\
\hline & \multicolumn{7}{c}{ TABLE 1 - Diagnostic methods according to the etiological agent of ABM. } \\
\cline { 2 - 7 } Diagnostic methods & Unspecified & H. influenza & S. pneumoniae & N. meningitidis & Other & Total (\%) \\
\hline Culture & 0 & 0 & 25 & 13 & 9 & $47(28.0)$ \\
Latex agglutination & 0 & 4 & 11 & 3 & 0 & $18(10.7)$ \\
Clinical signs & 38 & 0 & 0 & 0 & 0 & $38(22.6)$ \\
Gram stain & 0 & 0 & 5 & 0 & 0 & $7(4.1)$ \\
Necropsy & 2 & 0 & 0 & 0 & 0 & $2(1.2)$ \\
Cytochemistry & 56 & 0 & 0 & $\mathbf{1 8}(\mathbf{1 0 . 7 )}$ & $\mathbf{9 ( 5 . 4 )}$ & $\mathbf{1 6 8 ( 1 0 0 . 0 )}$ \\
\hline Total (\%) & $\mathbf{9 6 ( 5 7 . 1 )}$ & $\mathbf{4 ( 2 . 4 )}$ & $\mathbf{4 1 ( 2 4 . 4 )}$ &
\end{tabular}

TABLE 2- Outcome according to the etiological agent of ABM.

\begin{tabular}{lccccc}
\hline & \multicolumn{5}{c}{ Etiological agent } \\
\cline { 2 - 6 } Outcome & Unspecified & H. influenza & S. pneumoniae & N. meningitidis & Other \\
\hline Cure (\%) & $59(61.5)$ & $3(75.0)$ & $25(61.0)$ & $14(77.8)$ & $6(66.7)$ \\
Death (\%) & $10(10.4)$ & $0(0.0)$ & $6(14.7)$ & $2(11.1)$ & $1(11.1)$ \\
Unknown (\%) & $27(28.1)$ & $1(25.0)$ & $10(24.3)$ & $2(11.1)$ & $2(22.2)$ \\
\hline Total (\%) & $\mathbf{9 6 ( 1 0 0 . 0 )}$ & $\mathbf{4 ( 1 0 0 . 0 )}$ & $\mathbf{4 1 ( 1 0 0 . 0 )}$ & $\mathbf{1 8 ( 1 0 0 . 0 )}$ & $\mathbf{9 ( 1 0 0 . 0 )}$ \\
\hline
\end{tabular}

TABLE 3 - Antibiotic susceptibility of $S$. pneumoniae causing ABM*.

\begin{tabular}{lcccc}
\hline & \multicolumn{5}{c}{ Sensitivity level } \\
\cline { 2 - 5 } Antibiotic & $\begin{array}{c}\text { number of cases } \\
\text { tested }\end{array}$ & $\begin{array}{c}\text { susceptible } \\
\mathrm{n}(\%)\end{array}$ & $\begin{array}{c}\text { intermediate } \\
\mathrm{n}(\%)\end{array}$ & $\begin{array}{c}\text { resistant } \\
\mathrm{n}(\%)\end{array}$ \\
\hline Penicillin & 14 & $13(92.8)$ & - & $1(7.2)$ \\
Oxacillin & 4 & $4(100.0)$ & - & - \\
Ofloxacillin & 8 & $7(87.5)$ & - & $1(12.5)$ \\
Erythromycin & 19 & $15(80.0)$ & $1(5.0)$ & $3(15.0)$ \\
Clindamycin & 16 & $14(87.5)$ & $1(6.25)$ & $1(6.25)$ \\
Tetracycline & 12 & $11(85.7)$ & $1(14.3)$ & - \\
Chloramphenicol & 11 & $10(91.7)$ & - & $1(8.3)$ \\
Cotrimoxazole & 12 & $2(16.7)$ & $1(8.3)$ & $9(75.0)$ \\
Rifampicin & 19 & $17(89.5)$ & $1(5.25)$ & $1(5.25)$ \\
Vancomycin & 19 & $19(100.0)$ & - & - \\
\hline
\end{tabular}

* 17 strains were isolated from CSF and 3 from blood.
The high rate of failure to determine the etiological agent at GTH is consistent with other Brazilian reports, which range from 46.8 to $55.5 \%{ }^{3,6}$. Although only $6.5 \%$ of the patients in the current study reported previous use of antibiotics, which is most likely an underestimation, the low bacterial culture rate is probably greatly affected by the previous use of antibiotics ${ }^{5}$. In a Brazilian national study conducted by Mantese et $\mathrm{al}^{5}, 47.2 \%$ of the patients reported previous antibiotic use ${ }^{5}$.

S. pneumoniae was the most prevalent $\mathrm{ABM}$ etiological agent in our sample, but was associated with relatively low mortality (14.6\%), in comparison with previous reports referring to mortality rates greater than $30 \%$ for this bacterium ${ }^{7,1}$. However, the low mortality rate in our study might have been masked by the poor routine for data records at GTH.

Pneumococcal ABM is associated with conditions leading to immunological impairment, skull-brain trauma and CSF fistula? 
The occurrence of skull-brain trauma and CSF fistula in 13 cases of pneumococcal infection may also have accounted for the displacement of the mean age of disease onset to 29.8 years of age. Pneumococcal ABM was most frequent in children $<5$ years and the elderly, as reported worldwide ${ }^{8}$. Moreover, the lack of a pediatric ward at GTH over this period contributed towards the higher mean age of the patients in the study.

We found that $7.2 \%$ of the pneumococcus isolates were penicillin resistant, while there was no cephalosporin resistance. These rates are lower than the values found by Brandileone et $\mathrm{al}^{9}$, who reported that there was an increase in the numbers of cases of invasive penicillinresistant S. pneumoniae in Brazil, from $10.2 \%$ to $27.9 \%$, between 1993 to $2004^{9}$. Meningitis isolates were more frequently resistant to cefotaxime $(2.6 \%)$ than were non-meningitis isolates $(0.7 \%)$. However, generally, there is high susceptibility to cefotaxime in Brazil, thus supporting the use of third-generation cephalosporins as the drugs of choice for meningitis treatment in this country. These rates vary according to regions, and the northern and northeastern regions are less affected ${ }^{9}$. In this study, pneumococcus resistance rates to chloramphenicol $(8.3 \%)$, cotrimoxazole $(75 \%)$, erythromycin (15\%) and rifampicin (5.25\%) were higher than rates reported in another Brazilian study that showed resistance rates of $1.3 \%, 65 \%$, $6.2 \%$ and $0.7 \%$, respectively 9 .

The higher prevalence of the N. meningitidis serogroup B, in comparison with serogroup $\mathrm{C}$, conforms with previous Brazilian reports ${ }^{10,11}$. The cases of meningitis due to $H$. influenza do not fit within the preferential age range for this bacterium. Indeed, the current Brazilian incidence of Hib meningitis in this age range is only 0.02 cases for every 100,000 inhabitants $^{12}$.

The hearing loss experienced by $2.8 \%$ of the survivors was lower than the rate of $6.2 \%$ found in other Brazilian reports ${ }^{13}$. Our findings cannot be taken as an estimation of permanent sequels since the GTH lacks a follow-up program for patients after discharge.

Our identification of $S$. pneumoniae as the main agent of ABM in the young urban population requires preventive epidemiological attitudes towards this group. Because of the low rate of penicillinresistant pneumococci at GTH, careful planning of antibiotic usage and management of meningitis is important in order to avoid raising the pneumococcus resistance rate, which is increasing slowly in Brazil. Therefore, knowledge of the regional epidemiological profile is crucial for improve the diagnosis, treatment and prognosis of $\mathrm{ABM}$ patients.

\section{ACKNOWLEDGMENTS}

The authors would like to thank the laboratory and epidemiology department team of GTH, especially Mr. Dagoberto Mariz, Mrs. Alcilene Ribeiro Soares and Mrs. Graça Micussi.

\section{CONFLICT OF INTEREST}

The authors declare that there is no conflict of interest.

\section{FINANCIAL SUPPORT}

The authors received financial support from UBS Optimus Foundation (Switzerland). LFAG and LGC have fellowships from CNPq.

\section{REFERENCES}

1. Escosteguy CC, Medronho RA, Madruga R, Dias HG, Braga RC, Azevedo OP. Vigilância epidemiológica e avaliação da assistência às meningites. Rev Saude Publica 2004; 38:657-663.

2. Bryan JP, de Silva HR, Tavares A, Rocha H, Scheld WM. Etiology and mortality of bacterial meningitis in northeastern Brazil. Rev Infect Dis 1990; 12:128-135.

3. Romanelli RM, Araujo CA, Dias MW, Boucinhas F, Carvalho IR, Martins NR, et al. Etiologia e evolução das meningites bacterianas em centro de pediatria. J Pediatr 2002; 78:24-30.

4. Salih MA, Khaleefa OH, Bushara M, Taha ZB, Musa ZA, Kamil I, et al. Long term sequelae of childhood acute bacterial meningitis in a developing country. A study from the Sudan. Scand J Inf Dis 1991; 23:175-182.

5. Mantese OC, Hirano J, Santos IC, Silva VM, Castro E. Perfil etiológico das meningites bacterianas em crianças. J Pediatr 2002; 78:467-474.

6. Weiss DP, Coplan P, Guess H. Epidemiology of bacterial meningitis among children in Brazil, 1997-1998. Rev Saude Publica 2001; 35:249-255.

7. Durand ML, Calderwood SB, Weber DJ, Miller SI, Southwick FS, Caviness VS, et al. Acute bacterial meningitis in adults. A review of 493 episodes. N Engl J Med 1993; 328:21-28.

8. Schuchat A, Robinson K, Wenger JD, Harrison LH, Farley M, Reingold AL, et al. Bacterial meningitis in the United States in 1995. Active Surveillance Team. N Engl J Med 1997; 337:970-976.

9. Brandileone MCC, Casagrande ST, Guerra ML, Zanella RC, Andrade AL, Di Fabio JL. Increase in numbers of beta-lactam-resistant invasive Streptococcus pneumoniae in Brazil and the impact of conjugate vaccine coverage. J Med Microbiol 2006; 55:567-574.

10. Santos ML, Ruffino-Netto A. Meningococcal disease: epidemiological profile in the Municipality of Manaus, Amazonas, Brazil, 1998/2002. Cad Saude Publica $2005 ; 21: 823-829$.

11. Puricelli RC, Kupek E, Bertoncini RC. Control of a community outbreak of group C meningococcal meningitis in Corupa, Santa Catarina State, Brazil, based on rapid and effective epidemiological surveillance and immunization. Cad Saude Publica 2004; 20:959-967.

12. Miranzi SS, Moraes SA, Freitas IC. Trends in Haemophilus influenzae type b meningitis in Brazil in children under five years of age from 1983 through 2002. Rev Soc Bras Med Trop 2006; 39:473-477.

13. Romero JH, Carvalho MS, Feniman MR. Hearing findings in subjects after meningitis. Rev Saude Publica 1997; 31:398-401. 